\title{
CIVIL SZERVEZETEK BESZÁMOLÁSI KÖTELEZETTSÉGE, VÁLTOZÁSOK ÉS TÉNYEK
}

\author{
Szabados György Norbert - Bácsné Bába Éva - Fenyves Veronika - Bács Zoltán - \\ Helmeczi András - Balogh Renátó - Dajnoki Krisztina
}

\begin{abstract}
Absztrakt: Amennyiben ma Magyarországon a civil szféráról beszélünk, a törvényi szabályozás ellenére sem messze egyértelmủ kép tárul a laikus vagy épp a szakember számára. A KSH nonprofit tájékoztatóiban 1993 óta állnak rendelkezésre adatok, a bírósági online kereső civil szervezetek azonosítására, főbb adatainak megismerésére működtet adatbázist, mindemellett, ezektől függetlenül vagy épp ezekre alapozva kevés a további másodelemzés, vagy épp empirikus jellegü kutatás. A civil szervezetek beszámolási kötelezettségeivel kapcsolatos vizsgálódás újszerü területe a civilek kutatásának, apropóját pedig épp a sajtóban egyre több alkalommal megjelenő cikkek adják: civilek, akik nem tudnak támogatásokkal elszámolni, akik nem teszik közé beszámolóikat vagy épp az SZJA 1\% kapcsán vélelmezhető valamiféle anomália. 2011 óta a civilek beszámolói is hozzáférhetőek (vagy annak kellene lenniük) a bírósági online keresőben, és a kutatások célja ezzel összefüggésben pedig éppen az, hogy miként és hogyan változott a beszámolási kötelezettség, megfelelöen kitöltötteke a beszámolók, és mennyire hajlandóak részleteiben is beszámolni a szervezetek müködésükről. Az eredmények szerint úgy tünik, hogy a kevésbé kiélezett elvárásnak a beszámolási hajlandóság lazasága is velejárója.
\end{abstract}

\begin{abstract}
Considering the Hungarian civic sphere, its situation and characteristics are far from clear and unambiguous equally for nonprofessional and experts, despite the legal regulation. Nonprofit reports of The Hungarian Statistical Office provide data of the sector since 1993. The judicial online browser also runs a database to identify and acquire most important features of organizations of the civic sector. Still, there are only few results of secondary analysis or primary research, dependently or independently from them. The analysis of the reporting requirements seems to be novel field of the civic related researches, the main reason for the examinations are the latest media reports, where those organizations are highlighted, who cannot meet the subsidy related reporting requirement, who do not reveal their financial reports or simply there is some kind of an anomaly of the $1 \%$ personal income tax offering. Since 2011, civic organizations' reports are (or should be) available in the judicial browser, the objective of the examination is - in relationship with it - to understand how the way of reporting has changed and in what detail organizations are willing to report on their activities. Our results show that a not demanding reporting expectation of the court meets the reporting laziness of some of the civic organizations.
\end{abstract}

Kulcsszavak: civil szervezetek, sportszervezetek, beszámoló

Keywords: civil society organisations, sport organizations, financial reports

\section{Bevezetés}

Túl a 2019-es helyi önkormányzati választásokon sem csökken az érdeklődés a civil szervezetek iránt, különösen élénk ez az érdeklődés a politikatudomány és a közpolitikák irányából. A választásokon induló jelöltek civil támogatását, a nemzetközi civil szervezetek hazai szerepét, a nemzetközi civil szervezetek globális jogérvényesítési kezdeményezéseit éppúgy érdeklődés követi a hazai sajtóban, mint a nemzetköziben is. Amennyire néha túlzott is a figyelem a szakmai tevékenység irányába, úgy siklik el a politikusok, az intézményi szféra, vagy épp a kutatók érdeklődése is a szervezetekkel kapcsolatos minimális elvárásoknak való megfelelőség felett. Pedig erősen úgy tünik, hogy lenne helye ilyen érdeklődésnek 
is. A civil szervezetek által kötelezően közzéteendő beszámolók, az alapszabályok/alapító okiratok, támogatások mind-mind egymással szoros összefüggésben értendőek. Ilyen például az, ha egy szervezet be van jegyezve, minden év május 31-ig közzé kell tenni beszámolóját. A beszámolási kötelezettség sokat változott napjainkra, de nagyon úgy tủnik, hogy régi idők berögződései nehezen múlnak: némelyek beszámolnak, mások nem, sőt akik beszámolnak, azok sem mindig helyesen, a beszámoló formanyomtatványa szerinti elvárásnak megfelelően. A beszámolóban, legyen az teljes vagy részlegesen kitöltött, bizonyos adatok sokatmondóak a szakemberek számára, így indikátorok a társadalmi beágyazottságra (pl. az SZJA 1\%, a közhasznúsági társadalmi támogatottság mutatói), az erőforrás-ellátottságra (bevétel, vagyon), de akár a jó menedzsmentre vagy épp érdekérvényesítésre (pl. helyi önkormányzati támogatás, egyéb bevételek) is. A szervezetekről ilyen módon szerzett mélyebb információk a szféra jobb áttekinthetőségét teszik lehetővé, valamint hozzájárulhat a beszámolási hajlandóság erősítéséhez, illetve a specifikus elvárásokkal kapcsolatos alaposabb teljesítéshez.

\section{Szakirodalmi áttekintés}

A civil, nonprofit jelleg jelentése sem nemzetközi, sem történeti összehasonlításban nem egységes, ezért kezdetben számos szerző a fogalom és elnevezések meghatározásával, történetével, értelmezésével foglalkozott (Márkus-Pete, 2018). A szerzőkhöz közel álló menedzsment aspektus egyik nemzetközi irodalma szerint (Gough et al., 2009) Amerikában az NPO (Non Profit Organization) az elfogadott terminus, ahol a nonprofitság elsősorban az adólevonással, kedvezményekkel összefüggő státuszt jelent, melyen belül számtalan különféle szervezettípus müködik (pl. public charity, foundations, stb.). Az említett irodalom szerint a nonprofitok számára az egyik legjelentősebb kihívás az, hogy hogyan és kik szabályozzák őket, az állami ügynökségek ugyanis egyre nagyobb mértékben kíváncsiak az aktív NPO$\mathrm{k}$ pénzteremtési/gyüjtési tevékenységükkel kapcsolatos jelentéseikre. C.K. Prahalad, neves vezetési guru, a Guardain „The Most Influential Business Thinkers” 2007-es listájának élén álló indiai professzor sikerkönyvében (Prahalad, 2005) a nonprofitok és nem kormányzati szervezetek (NGO) tartalma ugyanaz, céljuk a szegénységgel és közegészségügyi krízisekkel kapcsolatos problémák enyhítése. Országonként változik a szektor domináns profilja, pl. Indiában a már említett szegénység enyhítése lehet a nyomatékos profil. Más szerzők is érvelnek amellett, hogy miért nem nagyobb a civilek figyelme a szegénység irányába, így felmerül a kérdés, hogy a civilek miért feministák vagy épp környezetvédők, és miért nem szegénységcsökkentők? A civileknek ugyanis kulcsszerepe kellene lennie az ilyen ügyek pártolásában, az ilyen ügyekben való részvételben és a fenntartható szegénységcsökkentés elősegítésében (Ibrahim - Hulme, 2010). Azt ugyanakkor nem lehet elvitatni, hogy ez a szervezeti típus ugyancsak plurális, mind szervezeti formátum, mind tevékenységi profil (repertoár), mind HR vonatkozások tekintetében. Itthon párhuzamosan a kultúra, a hobbi, sport és a hobbi, szabadidős tevékenység (melyek egy része szintén sport) profil teszi ki a klasszikus civilek (egyesületek és magánalapítványok) számának több mint felét. Az egyesülési jogról, 
a közhasznú jogállásról, valamint a civil szervezetek müködéséről és támogatásáról szóló 2011. évi CLXXV. törvény (ún. Civil törvény, Civiltv.) adja a legutóbbi keretet ezeknek a szervezeteknek a müködéséhez, melyhez egy sor további törvény is kapcsolódik. A témánk számára fontos szabályozás ebben a Civil törvényben található.

Amennyiben ma azt szeretnénk tudni, hogy egy civil szervezetnek miféle alapvető beszámolási kötelezettséget kell teljesítenie minimálisan, a Civil törvényben a VI. fejezet 11. „A beszámolási szabályok” címe alatt írtak (28-30.§§) tartalmaznak elöírásokat. Ezeket röviden érdemes áttekinteni és összegezni:

1. Minden civil szervezetnek az üzleti év (sic!) lezárását követően beszámolót kell készíteni, melynek formáját több minden (tevékenység, összes bevétel, könyvvezetés módja) határozza meg. Itt érdemes szót ejteni a változások kapcsán arról, hogy a 2011-es Civil törvény elött is valamennyi szervezettel szemben a beszámolási kötelezettség éppúgy érvényes elvárás volt. Ennek formátuma négyféleképp volt elérhető, attól függően, hogy a szervezet könyvvezetése egyszeres vagy kettős volt, és hogy a szervezet közhasznú volt-e vagy sem: így létezett a 1415-ös beszámolónak A, B, C és D verziója, amelyek csak a mérleg és eredménykimutatás lehetöségeiben különböztek. Ezek a dokumentumok nyomtatványboltban voltak beszerezhetőek, de sokan az interneten elérhető formátumokat használtak, melyek éppúgy elfogadottak voltak.

2. A civil szervezetnek a beszámolót letétbe kell helyeznie. Ez a 2011-es Civil törvény hozadéka, addig ezt senki nem várta el, némely, a társadalmi szervezetekkel foglalkozó akkori bírósági iroda ajtaján ki is volt függesztve, hogy nem kell leadni a beszámolót. A beszámolónak - noha el kellett készíteni - nem igazán volt tétje, ugyanakkor ez a kötelezettség specifikus támogatásokkal összefüggésben állt, így pl. az Nemzeti Civil Alapprogram (NCA) is kérte, az új Nemzeti Együttmüködési Alap (NEA) is. Ez utóbbinál jelenleg is érvényes szabály, hogy formailag érvényes pályázatot csak úgy lehet beadni, hogy a pályázatban előírt legutolsó éves beszámoló közzétett, vagy ha nem elérhető a törvényszéki keresőben, akkor is legalább a beszámolót feltöltötte, és a letéti igazolás is rendelkezésre áll.

3. A beszámoló letétbe nem helyezésének vannak következményei. Röviden erről csak annyit, hogy egyrészt pénzbírságot helyez kilátásba a jogszabály, ezen kívül pedig mivel a támogatások odaítélésének sokszor feltétele (vagy épp annak kellene legyen) a lezárt évröl szóló közzétett beszámoló, így a szervezet emiatt nem juthat támogatáshoz. Illetve az ügyészségnek, mint az általános törvényességi ellenörzési szervnek joga van felügyeleti eljárást kezdeményezni, melynek célja a törvényes müködés helyreállítása, de a bíróság a beszámoló letétbe helyezésének elmulasztása miatt erre vonatkozó jogszabályi kötelezettség hiányában közvetlenül nem kezdeményez ilyen eljárást. Pedig ez utóbbi az, ami „fájni” tud a szervezetnek, illetve vezetésének, ugyanis rendszerint ilyenkor az ügyészség bekéri az elmúlt év müködésének legfontosabb dokumentumait, így pl. közgyülési 
jegyzőkönyvet, tagi névjegyzéket, bankszámlakivonatokat, és hiány esetén további teendőket ír elő, amelyek néha nem is olyan egyszerü gyorsan, az elvártak szerint teljesíteni.

Különös sajátossága a beszámolók bírósági közzétételének, hogy sem formailag, sem szakmailag (tartalmában, érdemben) nem ellenőrzi a beszámolókat a törvényszék (birosag.hu/a). A formaiság követelménye egyébként viszonylag egyszerü módon, de részben érvényesül, ugyanis amióta ügyfélkapun (mára cégkapun) keresztül történhet a beszámolók benyújtása (elektronikus eljárásra kötelezettek, pl. a közhasznúak), úgy az Általános nyomtatvány programra (ÁNYK) a letöltött különbözö, PK (nonprofit nyomtatványok) elöjelü szükséges nyomtatványok ellenőrzését benyújtás elött maga a program ellenőrzi, és figyelmeztet a hibákra. Az ilyen eljárásra nem kötelezettek (pl. egy nem közhasznú alapítvány) beszámolóját ,az ÁNYK program használatával vagy annak mellőzésével lehet benyújtani postai úton" (birosag.hu/b). Az viszont teljesen nyilvánvaló, hogy a szervezetek beszámolóinak formai vagy szakmai helyességének, a nyomtatványok teljes és helyes kitöltésének kétségtelenül szigorú elvárásnak kellene lennie. Ennek okai közül csak néhányat sorolunk fel:

1. Ha egy szervezet nem adja meg jól pl. a támogatások részletezésére vonatkozó információkat, úgy a szervezet tevékenységének megítélése hibás lehet.

2. Mások is ,potya-utaskodhatnak” a rendszerben, azaz, ha egynek megengedi a hiányt, a többi sem fog teljes információt megadni.

3. Sok esetben ezek az egyetlen információforrások a helyi támogatások megítélésének sajátosságaival kapcsolatban. Számos település ugyanis rendre figyelmen kívül hagyja a különböző támogatások odaítélésével kapcsolatos pályázati felhívás, eredmények stb. közzétételét (a Nyírségben például ez a jelenség eléggé gyakori, érdemes rákeresni a települések honlapjára ezen hipotézis ellenőrzése végett). Így arról, hogy ki milyen támogatásban is részesült, az csakis a civil beszámolókból tudható meg. Ha van támogatás a civil szervezet beszámolójában a helyi önkormányzattól, akkor annak nyilvánosnak, átláthatónak és összeférhetetlennek (a pályázó és a döntést előkészítő, illetve -hozó szerv vagy személy függetlenek egymástól) kell lennie (ezt több törvény is szabályozza, pl. 2011. évi CXII. törvény az információs önrendelkezési jogról és az információszabadságról, 2007. évi CLXXXI. törvény a közpénzekből nyújtott támogatások átláthatóságáról stb.). Érdemes lenne megnézni, mint mond az elmélet (törvényi háttér) és mit mond a gyakorlat.

4. A beszámoló sokatmondó tud lenni azzal kapcsolatosan, hogy kik, elsősorban milyen forrásokat vesznek igénybe, és vajon van-e erre egyáltalán jogosultságuk (pl. deminimis támogatási feltétel).

5. Egyáltalán mennyire támogatásfüggő egy szervezet, azaz milyen részt képez a bevételeiben a támogatás, és vajon ennek felhasználása milyen módon történt meg. 
Feltételezhető, hogy az állami apparátusnak nincs arra sem ideje, sem energiája, hogy a közel 54 ezer klasszikus civil szervezet és más, ilyen módon történö beszámolásra kötelezett nonprofit beszámolóit tételesen átvizsgálja, és hiányosságokat állapítson meg, esetleg erre alapozva meg is tagadja a beszámolási kötelezettség teljesítésének elfogadását. Ugyanakkor a szakmai gyakorlat során tapasztalt hiányosságok, tendenciaszerüen előforduló hasonló jelenségek keltik fel a hozzánk hasonló kutatók figyelmét arra, hogy megpróbáljuk többet megtudni a civil szervezetek beszámolóival kapcsolatos hiányosságokról, azok részeinek mélyebb összefüggéséről. Az ilyen kérdésekre a választ a szervezetek adatainak tételes lekérdezése, rögzítése majd pedig kiértékelése kapcsán tudhatjuk meg.

\section{A vizsgálat anyaga és módszere}

A korábbiakban már említettek szerint a civil szervezeteket beszámolási kötelezettség terheli. A beszámolók megküldést követően a www.birosag.hu-n elérhetővé válnak, a szervezetek korábbi beszámolói is elérhetőek a törvényi kötelezettség érvénybe lépését követően (már amennyiben egy szervezet azt teljesítette). A kutatócsoport területi elhelyezkedése, kapcsolatai, elérhetőségei miatt az ország megyéi közül Hajdú-Bihar megyére esett a választásunk. A bírósági nyilvántartással és lekérdezhetőséggel kapcsolatos problémák sajnos már az elején megjelennek. A kereső régebbi verziója egy hasonló kutatást teljes mértékben kiszolgált volna. A jelenleg használt verzió egyrészt csak több változó beállítását követően adja meg a szükséges adatokat.

A kutatás korlátai:

1. Megyénként keresni nem lehet, így a keresőben (https://birosag.hu/civilszervezetek-nevjegyzeke) az eljáró bíróság nevénél a Debreceni Törvényszéket adtuk meg

2. Külön kell lekérdezni az egyesületeket és az alapítványokat

3. A "cél szerinti besorolásnál" lehet választani sporttevékenység, valamint sporttevékenység (pl. fizikai, szellemi és technikai stb. sport) lehetőség között. Ez igazából nem érthető, mivel ez utóbbi része az előbbinek. Emiatt ezt is tesztelni kellett, hogy vajon mennyiben különbözik a kettő. Sajnos különbözik az ez alapján lekérdezhető szervezetek listája

4. A "szervezet típusa” változó beállításnál újabb választási lehetőség jelenik meg, felsorolva többek között az egyesületet, sportegyesületet stb. Ez a kettő is átfedi egymást

5. A cél szerinti tevékenység sport attribútum esetében csak az ilyen tevékenységet főtevékenységként bejegyző szervezetek jelennek meg. Ez azért hibás gondolkodás, illetve torzíthat, mivel számos egyéb célszerinti tevékenységgel rendelkező szervezetnek is lehet sporttevékenysége, és ezek a felmérésből kimaradnak.

A lekérdezés tehát a fentiek figyelembevételével úgy történt, hogy ceteris paribus valamennyi változót helyben hagyva kiválasztottuk az illetékes törvényszékeket (debreceni), majd a szervezet típusát (egyesületalapítvány/közalapítvány), és a cél szerinti besorolásnál beállítottuk mindkét féle 
sporttevékenységet. Az alappopuláció sporttevékenység esetében 367 egyesület és 19 alapítvány, sporttevékenység (pl. fizikai stb.) esetében 143 egyesület és 8 alapítvány, ez képezi a törvényszéki adatbázist tekintve a hajdú-bihari sportcivil szervezetek körét. Itt a mintavétel szisztematikus, ahol valamennyi sport- vagy sport (pl. fizikai stb.) cél szerinti tevékenységgel foglalkozó Hajdú-Bihar megyében bejegyzett alapítványt lekérdeztünk, valamint sport cél szerinti tevékenység esetében minden 3., sport (pl. fizikai stb.) cél szerinti tevékenység esetében minden 2. szervezet adatai lekérdezésre kerültek, a pótcímezés aránya alacsony maradt. A minta tehát összességében 217 hajdú-bihari sport vagy sport (pl. fizikai stb.) cél szerinti tevékenységgel rendelkező egyesület és alapítvány. Mindkét kutatás adatai SPSS rendszerbe kerültek rögzítésre, majd kiértékelésre.

A módszer maga dokumentum elemzés, ami jelen esetben azt jelentette, hogy a feltöltött szervezeti beszámolókon a meghatározott változók keretében rögzítettük az egyes attribútumokat. A települési és az általános szervezeti adatokon túl két dimenzió alapján történt az adatgyüjtés, ahol a beszámolási dimenzió változói a beszámolási kötelezettség teljesítésével kapcsolatos adatokat rögzítették, míg az adatbázis legjelentősebb részét kitevő tárgyévi pénzügyi adatok rész a legutolsó közzétett beszámolóban egyes részek kitöltöttségét, támogatási sajátosságokat, illetve ezek egyes további összefüggéseit rögzítették. Ebben a tanulmányban mi elsősorban az egyes támogatási sajátosságokat, illetve az ezzel összefüggésben lévő adatlapok kitöltöttségét igyekszünk górcső alá venni, a kiértékelés során pedig elsősorban leíró statisztikát és mélyebb összefüggések megállapításához szükséges magasabb statisztikát alkalmazunk.

\section{Eredmények}

Amennyiben, ha egy szervezet beszámolóját közzéteszi, annak felépítése a következőképpen néz ki:

1. általános szervezeti adatok

2. mérleg

3. eredménykimutatás

4. eredménykimutatás 2 - támogatásrészletező

5. közhasznú jogálláshoz szükséges mutatók

6. kiegészítő melléklet - támogatások tételenkénti ismertetése (pl. forrás, összeg, felhasználás).

Gépi kitöltés esetén gyakorlatilag az első 5 kitöltése nélkül be sem lehet küldeni a beszámolót. A 6 . tétel akkor töltendő ki, ha volt támogatás, és ahány, annyi kiegészítő mellékleti oldal. A fentiek alapján látható, hogy amennyiben egy szervezet támogatásban részesült, akkor az Eredménykimutatás „3. Egyéb bevételek" részen kívül (ugyanis ott meg kell adni a támogatások összegét) még legalább 2 helyen, az Eredménykimutatás 2. és a Kiegészítő mellékletben is részletezni kell a támogatások egyes sajátosságait. Legalábbis kellene. Ugyanis korábbi törvényszéki lekérdezések kapcsán tủnt fel, hogy igen sok szervezet hagyja figyelmen kívül ezeket a részeket, és nem adja meg a szükséges adatokat. Így ennek megfelelően adta magát az első kutatási szempont, hogy vajon milyen mértékben 
hajlandóak a szervezetek adatokat megadni abban az esetben, ha támogatáshoz jutottak. Hipotézisként $(\mathrm{H} 1)$ feltételezhetjük, hogy a támogatásban részesült szervezetek legalább 90\%-a szabály és elváráskövetö, azaz a támogatást kapó szervezetek legalább ekkora hányada tölti ki az Eredménykimutatás 2. részt helyesen. Az ezzel kapcsolatos felmérés eredményeit az 1. ábra mutatja be:

\section{1. ábra: A támogatás elérése és az Eredménykimutatás 2. adatlap kitöltöttségének összefüggése}

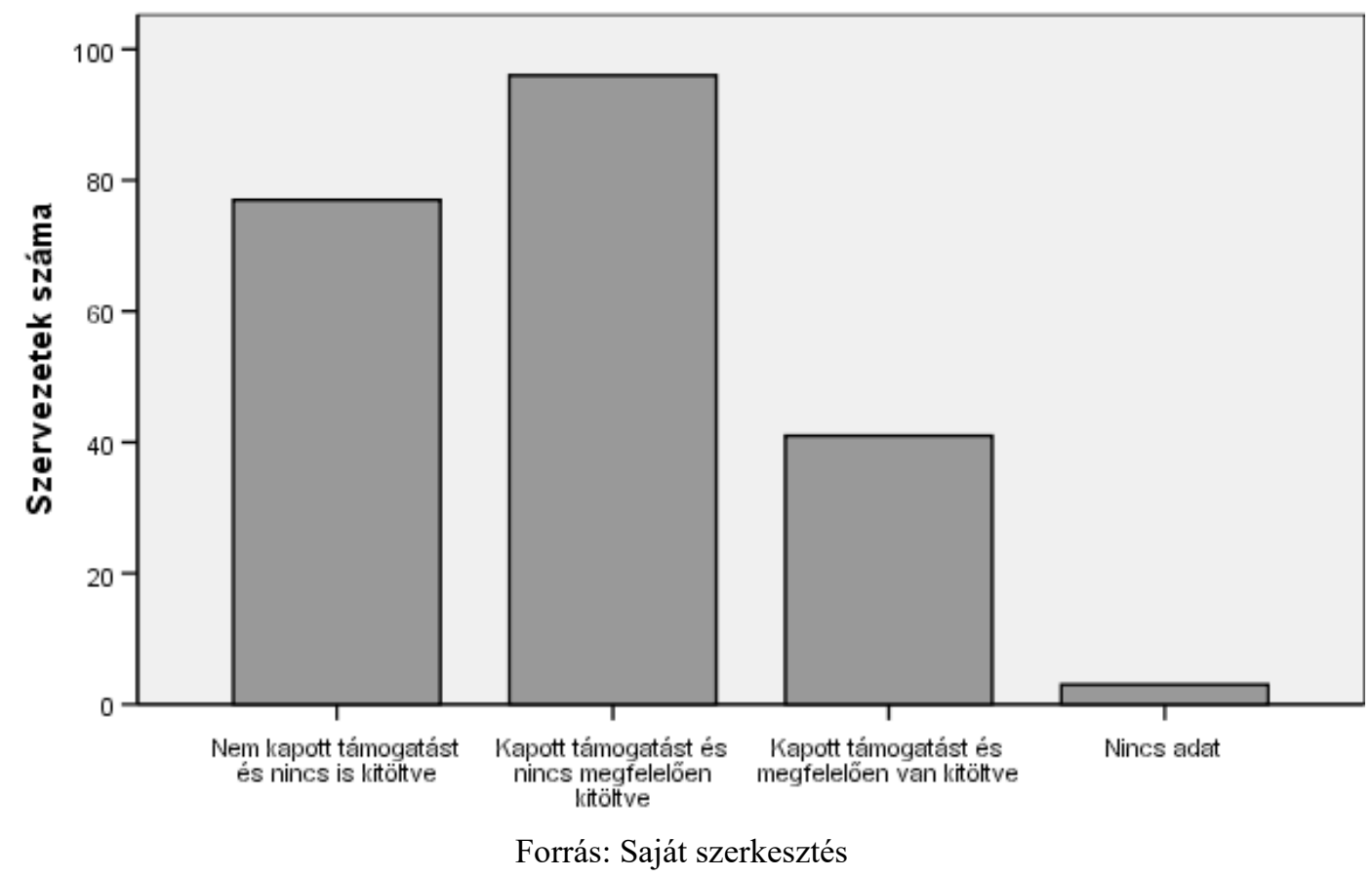

Az eredmények sokatmondóak, és még nagyon komment sem kellene. 77 szervezet (a szervezetek 35,55\%-a) nem kapott az adatok alapján semmiféle támogatást, 3 szervezet esetében pedig az eredménykimutatás hiányosságai miatt semmiféle adat nem áll rendelkezésre. 137 szervezet (a szervezetek 63,1\%-a) kapott támogatást az adott időszakban (csak megjegyeznénk, hogy a KSH legutóbbi tájékoztatója szerint a klasszikus civilek esetén a támogatások aránya $64,1 \%$, sportcivileknél még ennél is magasabb a támogatások aránya a bevételek között (72,5\%) (KSH, 2019). A felmért szervezetek közel 50\%-a (44,2\%, azaz 96 szervezet) részesült a felmért adatok szerint támogatásban, ám az Eredménykimutatás 2. adatlapon szükséges részletezés problémás. Ez több esetben egyszerüen és szimplán nincs kitöltve, más beszámolók esetében pedig az eredménykimutatás fő adatlapjával összevetve mutatnak eltérést, azaz vagy itt, vagy ott nem egyeznek a számok. A H1es hipotézis tehát egyértelmủen elvetendő. A további változókkal való összefüggést tekintve az egyesületek vélhetően valamelyest szabálykövetőbbek, ott kevesebb, mint felük (43\%) nem megfelelően töltött ki adatlapot, míg az alapítványok esetében ez pont a szervezetek felét jelenti. Felmerülhet a kérdés, hogy vajon a támogatások 
elérése és a szabálykövetés összefüggésben állhat-e egymással, azaz minél több támogatást kap annál kevésbé szabálykövetőbb az Eredménykimutatás 2. esetében? A Chi-négyzet próbát elvégezve közel ugyanazok az arányok (30:24:46) fordulnak elö, így nem igaz az, hogy minél több támogatást kapnak (11-es), annál kevésbé szabálykövetőbbek.

A kiegészítő melléklet „támogatások tételenkénti ismertetése (pl. forrás, összeg, felhasználás)" elviekben kötelező része lenne a szervezeti beszámolónak, ahol ismételten részletezni kellene a szervezeti támogatásokat, ezúttal azonban programonként. A KSH már említett legutóbbi tájékoztatója [7] 12 különböző támogatásfélét mutat be, köztük kétségkívül a legnagyobb a nem normatív alapú támogatások aránya $(24,2 \%)$, ezt a szervezetek 15,2\%-a éri el. Nehéz ennyi támogatásféleséget átlátni, számon tartani, és a beszámolókkal kapcsolatos korábbi feltáró jellegủ vizsgálódások kapcsán tủnt fel, hogy az ezzel kapcsolatos részletezés sem minden lekérdezett szervezet erénye. Itt már érdemesebb az eddigiek fényében alacsonyabb szintre helyezni becslésünket, és $\mathrm{H} 2$ hipotézisünket úgy fogalmaztuk meg, hogy a támogatásban részesült szervezetek legalább 50\%-a (azaz minden második) ennek a résznek az adatait megfelelően fogja kitölteni. Az eredményeinket a 2. ábra mutatja be:

\section{2. ábra: A kiegészítő melléklet támogatási adatainak forrásonkénti kitöltöttsége a támogatásban részesült szervezetek között}

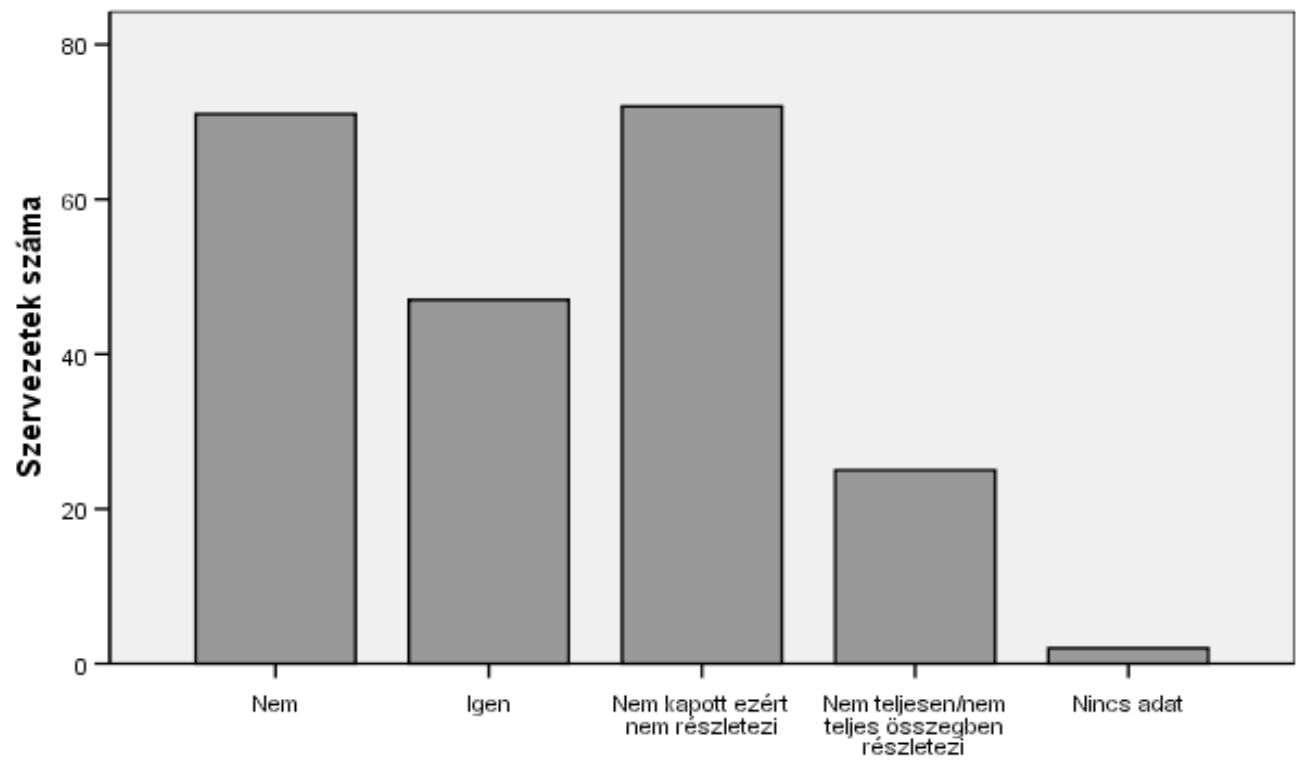

Forrás: Saját szerkesztés

Az eredményeket sarkosítva elmondható, hogy a támogatásban részesült szervezetek mindössze 32,8\%-a (47 szervezet) teljesen szabálykövető, azaz a H2 hipotézis is elvetendő. A támogatott szervezetek több, mint fele (71 szervezet) egyértelmüen normaszegö, mivel semmiféle ilyen adatot nem tettek közzé, és a támogatott szervezetek közel 18\%-a pedig csak részben adott meg valamiféle adatot 
(az eredménykimutatás két adata alapján ugyanis egyértelmủen meghatározható, hogy jó-e a kiegészítő mellékletben közölt adat). Alapvetően ez, összevetve az eredménykimutatás hiányosságaival, mutat rá arra az aggasztó jelenségre, hogy jelentősebb törvényszéki ellenőrzés hiányában a szervezetek igen jelentős része nem foglalkozik/nem veszi komolyan a beszámolási kötelezettségét. A támogatások mértéke összefüggésben lehet ennek a résznek a kitöltöttségével is, így hasonló módon felmerülhet a kérdés, hogy minél több támogatást kap a szervezt, annál szabálykövetőbb lesz? A támogatások mértékét tekintve elmondható, hogy a felmért szervezetek elsősorban az 1 millió Ft feletti támogatások esetében figyelnek jobban oda a részletezésre (ott már 50-50\% részletez vagy nem), a kisebb mértékben támogatottak kevésbé részleteznek, ugyanis a nem részletezők aránya itt már 80\%$90 \%$ körüli.

A támogatások, a már említettek szerint erősen áthatják ezt a szférát, és úgy tünik, hogy a szervezetek egy igen jelentős része részesül támogatásokban. A támogatások különbözöségével, sokféleségével párhuzamosan is vélhetően különbözik a szervezetek által elért támogatások nagysága. Korábbi adatok szerint (Murányi-Szerepi, 2005) a magyarországi civil szektor számos feszültséggel küzd. A költségvetési források eloszlása egyenetlen. A szektor megosztott, az együttmüködés helyett inkább a rivalizálás dominál, és kialakult egy erös támogatás dependencia. Az adataink szerint érzékelhető ez a polarizáció, és nem feltétlenül piramisszerüen (azaz nem a szervezetek egyre kisebb része részesült egyre nagyobb támogatásban), ugyanis a támogatásban részesült közel 65\%-nyi szervezet közül közel 60 (azaz az összes szervezetek közel 28\%-a) kap 1 millió Ft-nál nagyobb mértéken támogatást. 251 ezer Ft és 1 millió Ft közötti nagyságrendben kapott támogatást a szervezetek 15,2\%-a, és 250 ezer Ft vagy alatta összegben a szervezetek 20,3\%-a volt támogatott.

A KSH 2016-os adatbázisa szerint az államháztartás alrendszerének számító önkormányzati rendszer is jelentős támogatást biztosít a civil szervezeteknek (KSH, 2018). A normatív és nem normatív támogatások a szervezetek 21,2\%-át érik el (azaz elvileg minden ötödiket), ahol messze a leghangsúlyosabb (20,1\%) a nem normatív részesedés, azaz erősen úgy tünik, hogy az önkormányzatok esetében ez a dominánsabb támogatási forma (a megítélt összegben az arány már csak 1:5-höz a nem normatív javára). Egyes települések, forrásaik függvényében bő vagy szükkezüen bánnak a helyi civil szervezetekkel. A helyi civil szervezet általánosan a település székhelyén bejegyzett civil szervezetet jelent, ám sokszor nem csupán azok juthatnak helyi forrásokhoz. A helyi civilek és helyi politika viszonya nem teljesen független (a Civil törvény $2 . \S 22$ pontja definiálja a közvetlen politikai tevékenységet, ami azért nem ellentmondás, mert a politikai pártok jogilag egyesületnek minősülnek, persze a müködés során további szabályoknak kell megfelelniük), és egyes helyi források sokszor bőkezübbek, mint azt a település lehetőségei megengednék, valamint a legnagyobb egyenlötlenségeket itt lehet felfedezni, párhuzamosan sajnos a már említett törvényességi hibákkal. Arra vonatkozóan is van adatunk, hogy milyen a hajdú-bihari minta önkormányzati támogatási érintettsége (3. ábra). 


\section{3. ábra: A hajdú-bihari felmért szervezetek önkormányzati támogatási érintettsége}

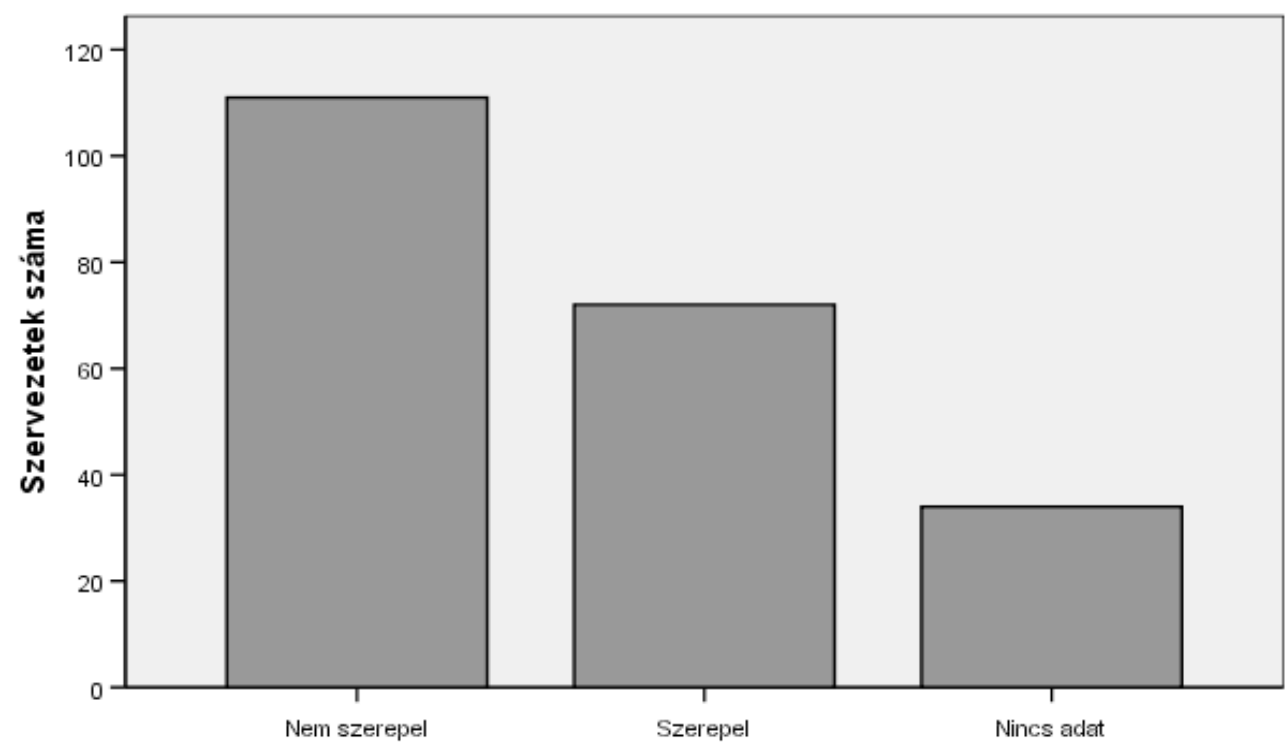

Forrás: Saját szerkesztés

Az eredmények szerint a felmért szervezetek esetében nagyobb a KSH-hoz képest megadott érintettség, mivel jelen esetben 72 szervezet (a felmért szervezetek $33,2 \%$-a) részesült önkormányzati támogatásban saját közzétett beszámolóik szerint. Sajnos itt ismét belefutunk a már említett részletezési hiányosságokba, mivel elképzelhető, hogy ennél több szervezet is kapott, ám részletes adatok hiányában csupán ennyi mondható biztosnak, valamint az is tény, hogy a jól kitöltött beszámolók esetében 51,2\% esetében nem mutatható ki önkormányzati támogatás. Ez egyébként egy viszonylag magas szám és a tapasztalatok szerint még ezek a támogatások is erősen polarizáltak, és egyaránt megtalálható benne a sokak kevese és a kevesek soka. Számos esetben fordul elő helyi szinten a támogatások elérésével kapcsolatosan a korlátozott pluralizmus. Pupek és Vass (2009) szerint a pluralizmus jelentése: többféle, azaz valamiből többféle van. Mint már láttuk az önkormányzati támogatásokból is van normatív és nem normatív, de itt a korlátozott pluralizmus jelzőt olyan értelemben használjuk, hogy egy szervezet különféle okok miatt csak, vagy elsősorban az önkormányzati támogatásra hajt, azaz ezen kívül vagy nincs, vagy csak valamiféle kisebb egyéb bevétele van. Ez a fajta összefüggés, azaz az önkormányzati támogatási dominancia ugyanakkor növeli a szervezet kiszolgáltatottságát a politikának, és ahhoz a korlátozott magatartás ahhoz is vezethet, hogy a szervezet nem is igazán igyekszik a magasabb törvényességi kötelezettségnek megfelelni. Eredményeink arra utalnak, hogy az korlátozottan plurális önkormányzati támogatási érintettség alapvetően nem magas (4. ábra). 


\section{4. ábra: A hajdú-bihari felmért szervezetek önkormányzati támogatási érintettsége, különös tekintettel a korlátozott pluralizmusra}

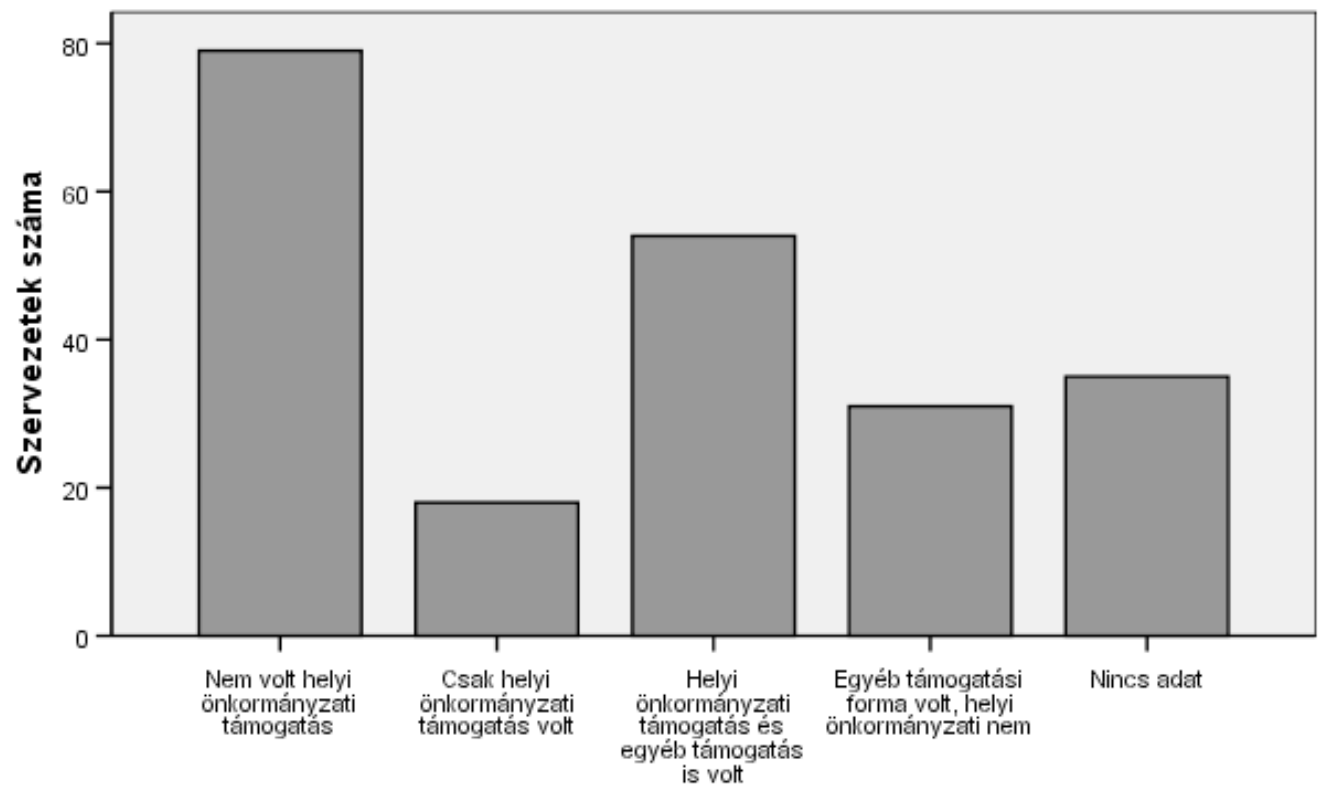

Forrás: Saját szerkesztés

Azon szervezetek száma, ahol csakis önkormányzati támogatás szerepelt, mindössze 18 (a szervezetek 8,3\%-a), és további 54 olyan szervezet van, ahol az önkormányzati mellett egyéb támogatás vagy bevétel is szerepel. Azt is meg kell említeni (kereszttábla elemzés eredményeként), hogy kisebb települési szinten (falvakban) sokkal inkább jellemzőbb, hogy a szervezet csak önkormányzati támogatást kap, városi szinten pedig sokkal jellemzőbb az a jelenség, hogy egy szervezet nem csak korlátozottan plurális. Itt egy érdekes jelenséget mindenképp érdemes megemlíteni, ez pedig az önkormányzati támogatások körén kívül lévő szervezetek száma. Nem minden szervezet tud beágyazódni az önkormányzati támogatási rendszerbe, sokszor ez pedig nem is a civil szervezetek hibája. Az eredmények utalnak arra, hogy igen jelentős az a 36,4\% (ez 79 szervezet), ami mintegy kívül reked az önkormányzati támogatási hálón. Viszont a támogatási rendszeren kívül helyi szinten is lehet esély „belső” forrásteremtésre, melynek a legtöbb esetben a kapcsolati háló a forrása, ez alatt értjük az SZJA 1\% elérhetőséget. Ma Magyarországon messze ez a legtöbb szervezetet átható támogatási forma, elérve gyakorlatilag a klasszikus civil szervezetek alig több, mint 50\%-át (50,35\%) (Gough et al., 2009). A mi mintánkban 57,6\% (125 szervezet) esetében nem volt a beszámolóban nyoma SZJA 1\% felajánlásnak, a szervezetek 28,6\%-a (62 szervezet) esetében pedig különféle összegek azonosíthatóak, ahol 9,7\% 50 ezer Ft alatti, 14,3\% 51 és 250 ezer Ft közötti, 4,6\% pedig 251 ezer és 1 millió Ft közötti SZJA 1\%-ot gyüjtött, 1 millió Ft feletti támogatottal nem találkoztunk. 30 szervezet esetében nem volt erre vonatkozóan semmi adat a hibás kitöltés miatt. 
Végezetül, itt is felmerül a kérdés, hogy ha csak helyi vagy nem csak helyi önkormányzati támogatás van, akkor kevésbé vagy inkább szabálykövetőbbek-e a szervezet pl. az Eredménykimutatás 2 kitöltöttsége esetében. Arra gondolhatnánk logikusan, hogy a csak helyi szinten kedvezményezett szervezetek kevésbé szabálykövetőbbek. Az eredmények ugyanakkor arra utalnak, hogy pont a fordítottja érvényes, mivel amennyiben csak helyi önkormányzati támogatás volt, úgy többségében (közel 66\%) megfelelően volt kitöltve, míg, ha csak más támogatás volt, úgy inkább az a jellemző, hogy kapott támogatást és nincs megfelelöen kitöltve, közel ugyanekkora (65\%) arányban.

\section{Következtetések}

Kutatási érdeklődésünk középpontjában a civil szervezetek beszámolási kötelezettségének egyes sajátosságai álltak. Nem lehet kétséges, hogy a civil szervezetekkel szemben támasztott beszámolási kötelezettségek teljesítése messze nem könnyü, már csak azon egyszerü oknál fogva sem, hogy a kapott támogatásokkal kapcsolatos adatokat több helyen és különböző megközelítésben kell feltüntetni és részletezni. A két, viszonylag egyszerüen megfogalmazott hipotézis elvetése, valamint a továbbiakban végzett elemzés mind arra világít rá, hogy a civil szervezetek egy jelentős része nem képes teljesíteni a velük szemben megfogalmazott, a támogatások feltüntetésével, részletezésével kapcsolatos beszámolási elvárást. Miután az látható, hogy noha komplex, de nem lehetetlen az efféle elvárásokat teljesíteni, így mutattunk rá arra az aggasztó jelenségre, hogy jelentősebb törvényszéki ellenőrzés hiányában a szervezetek igen jelentős része nem foglalkozik/nem veszi komolyan a beszámolási kötelezettségét. A korlátozott pluralitás mindenképp említésre méltó és érdekes jelenség, de a mintánk eredményei ezt a teljes mintára nem tudták megerősíteni, ugyanakkor megjegyzendő, hogy falusi szinten inkább megfigyelhető jelenségről van szó a városihoz képest.

\section{Köszönetnyilvánítás}

A publikáció elkészítését a EFOP-3.6.2-16-2017-00003 számú projekt támogatta. A projekt az Európai Unió támogatásával, az Európai Szociális Alap társfinanszírozásával valósult meg.

\section{Irodalomjegyzék}

Birosag.hu/a <https://birosag.hu/hirek/kategoria/ugyfeleknek/figyelemfelhivas-ismetelten-tobbbejelentes-erkezett-civil> (2020.01.08.)

Birosag.hu/b <https://birosag.hu/civil-eljarasok/beszamoloval-kapcsolatos-tajekoztato/hasznostudnivalok $>(2019.11 .26)$

Gough, J., Harper, K.A., Hill, S.D., Selden, H.M. (2009): Encyclopedia of Management. Cengage Learning, Gale.

Ibrahim, S., Hulme, D. (2010): Has civil society helped the poor? A review of the roles and contributions of civil society to poverty reduction. BWPI Working Paper 114. University of Manchester Brooks World Poverty Institute.

KSH (2018): <http://www.ksh.hu/apps/shop.kiadvany?p_kiadvany_id=1000704\&p_temakor_kod= KSH\&p_lang=HU> (2019.11.05) 
KSH (2019): A nonprofit szektor legfontosabb jellemzői, 2017. <http://www.ksh.hu/docs/hun/xftp/ stattukor/nonprofit/nonprofit17.pdf> (2019.09.05)

Márkus E., Pete N. (2018): Civil ismeretek a közösségi müvelődésben. Nemzeti Művelődési Intézet.

Murányi I., Szerepi A. (2005): Civil esélyek Hajdú-Bihar megyében. Hajdúsági Hallgatói Önkormányzatok Kulturális Egyesülete, Debrecen.

Prahalad, C.K. (2005): The Fortune at the Bottom of the Pyramid. Wharton School Publishing, New York.

Pupek E., Vass L. (2009): A politikatudomány alapjai. Budapesti Kommunikációs és Üzleti Főiskola, Budapest. 